\title{
Phenomenology and ethics of pregnancy
}

\section{Fenomenología y ética del embarazo}

Ilaria Malagrinò *

Department of Educational Sciences, Roma Tre University, Rome, Italy

\begin{abstract}
Nowadays, medicalization and technicalization of human gestation have led to extraordinary progress in procreation, opening to a new way of giving birth. Although, the practices of assisted reproduction seem to be an effective response to the desire for parenthood, nevertheless, they are arising many ethical dilemmas. To face them, we need a deeper reflection on the nature and essence of human gestation. Thus, in this paper I will analyze the perspective of some feminist thinkers centered on the category of pregnant embodiment as a lived experience to be able to answer what is a pregnancy and then to highlight its ethical intrinsic dimension with its practical implications.
\end{abstract}

Key words: Philosophy of pregnancy. Pregnant embodiment. Feminist philosophy.

\section{Resumen}

En la actualidad, la medicalización y tecnificación de la gestación humana ha supuesto un extraordinario avance en la procreación, posibilitando una nueva forma de dar a luz. Si bien las prácticas de reproducción asistida parecen ser una respuesta efectiva al deseo de paternidad, están planteando múltiples dilemas éticos. Para afrontarlos necesitamos una reflexión más profunda sobre la naturaleza y esencia de la gestación humana. Para abordar este tema, en este artículo analizaré la perspectiva de algunas pensadoras feministas centradas en la categoría de "encarnación" en el embarazo como experiencia vivida para poder responder qué es un embarazo y luego resaltar su dimensión ética intrínseca con sus implicaciones prácticas.

Palabras clave: Filosofía del embarazo. Encarnación en el embarazo. Filosofía feminista.

Correspondence:

Ilaria Malagrinò

E-mail: ilaria.malagrino@uniroma3.it
Available online: 13-12-2021 BIOETHICS UPdate 2021;7(2):117-124 www.bioethicsupdate.com 2395-938X / @ 2020 Centros Culturales de México, A.C. Published by Permanyer. This is an open access article under the license CC BY-NC-ND (http://creativecommons.org/licenses/by-nc-nd/4.0/). 


\section{Introduction}

Nowadays, medicalization and technicalization of human gestation have led to extraordinary progress in procreation, opening to a new way of giving birth. Although, the practices of assisted asexual reproduction, in vitro fertilization, gamete donation, and surrogacy seem to be an effective response to the desire for parenthood, and, at the same time, a ridding from the stigma of infertility; nevertheless, it seems legitimate to ask whether the benefits produced are greater or equal to the risks involved, and whether these techniques represent a new form of violence against women, children, and their bodies ${ }^{1}$.

Indeed, in addition to the risk of psycho-physical complications linked to the techniques used, there is the possibility of psychological complications as well due to the manipulation of the close relationship between gestational mother and baby. Surrogacy, for example, could be considered as a high-risk emotional experience, especially for the surrogate mother.

Thus, the many arising socio-ethical issues are dividing the bioethical debate. Different moral perspectives on biotechnologies of birth have the potential to result in an irresolvable stalemate and in practical anarchy, without any concern for the dangerousness involved. To get out of the impasse, we need a deeper reflection on the nature and essence of human gestation. However, this task seems to be particularly arduous.

Pregnancy is increasingly present in contemporary culture. Through advertising on maternity clothes, medical technologies, child care, birth control, abortion, baby care books, laws regarding birth, adoption and custody, and media depiction of pregnancy is a pervasive reality ${ }^{2,3}$. However, its richness and complexity are often reduced.

Furthermore, even from a philosophical point of view, we lack an adequate reflection. In this regard, feminisms has long theorized on the fact that philosophical thought has focused more on death than on birth ${ }^{4}$. Symbols of the phenomenon of embracing life by way of death are Cicero, with his saying "to philosophize is to learn how to die," and Heidegger, who claimed that being-toward-death constitutes the authentic attitude toward life ${ }^{5}$. As a result, although scholars have long relied on experience as a source for theoretical insight, they have long misunderstood birth and completely ignored pregnancy. Hence, an "unrecognized truth" calls us to reflect philosophically on one of the most meaningful structures of human existence.

Although we still lack adequate theories and theoretical categories to capture this experience, the aim of this paper is to explore this inherently fascinating event in its irreducibility to other phenomena. Indeed, pregnancy is a "biographical fact" that has in the body its main expression. Adopting this point of view will enable us to highlight the exceptional nature of this too often forgotten experience and its intrinsic and peculiar "ethicality."

To deal with this subject, in the next paragraph I will analyze the perspective of some feminist thinkers centered on the category of pregnant embodiment as a lived experience to be able to answer the question what is a pregnancy and, in the last, to highlight the ethical dimension intrinsic to it with its practical implications. 


\section{Pregnant embodiment}

Irigaray ${ }^{6}$ and Kristeva characterize pregnancy as a dynamic becoming that occurs and leaves its mark primarily in the body ${ }^{7}$.The maternal body is the silent privileged witness of metamorphosis that takes place over 9 months. It changes and becomes different, large and plump. Ankles are tumescent; breasts are heavy and swollen; nipples become tender in their dark red, leaking colostrum into the bra; the belly swells into a pear, becoming tougher; the skin rips apart; veins and stretch marks tattoo the hips, the arms, and the surface of the breasts.

According to Maher, the pregnant body refuses a stable connotation or morphology, continually redesigning its spatial coordinates in its movement outward toward its environment. It presents itself as a question because it is both a sign of contestation and affirmation. The contradiction seems to characterize each stage of its dialectical becoming. At the same moment, it is a sign of cessation and a point of stasis of the natural cyclicality of a woman's body. However, it opens up a new periodicity, where the natural "instability" of the menstrual flow is replaced by a new engagement in reproductive activity.

It is unthinkable in its "dichotomous unity." It is neither one nor two, yet it is one and two. In this regard, Irigaray says: "rigorously speaking, she cannot be identified either as one person, or as two she resists all adequate definition"8. Indeed, from an external and morphological point of view, the pregnant body is a singular and unified body. But from an anatomical and functional point of view, it contains the body of another. Young describes this particular "twoness in oneness" as a sense of movements "wholly mine," completely "within me", conditioning "my" experience and space, and even though they are another's. "I move as if I could squeeze around chairs and through crowds as I could 7 months before, only to find my way blocked by my own body sticking out in front of me, but yet not me, since I did not expect it to block my passage" ${ }^{\prime 9}$. Hence, it is simultaneously the preservation and the subversion of the body's integrity. Indeed, the pregnant body symbolizes penetration and incorporation; this body of one is at the same time the body of two. During gestation, mother and fetus are two distinct individuals and their bodies show a proper functioning, but they share the same material space. In their changes of nourishment and hormonal substances, they are two corporeal entities but at the same time one. In this sense, "pregnancy [...] models new corporeal possibilities, where the engagement with another corporeal entity represents productivity and no threat"10.

The sign of this particular tension between connection and distinction is the placenta. Placenta is a deciduous organ that is a temporary organ that exists only in the process of pregnancy. It is expelled after the period of gestation, rejected by both the maternal and the fetal bodies. It is formed from the embryo and it is imbricated in the maternal endometrium. Hence, it is closely linked to both bodies, but at the same time is separated from both. The placenta, therefore, despite being formed from the embryo, is almost independent from it, and plays a mediation role at two levels. It is placed "between" the fetal and maternal entities. In this way, there is no fusion between the maternal and fetal tissues. Simultaneously, it is the point of exchange of nourishment, blood, and waste fluid between the embryo and the mother that is the point where the cross-over occurs. Hence, the placenta is a complex system of regulation of exchanges. Furthermore, it changes the maternal metabolism so that the fetus can grow without harm the mother. More importantly, the 
placenta prevents the rejection of the embryo by the mother's body which recognizes it as herself and as another at once. In this reading, paraphrasing Maher, we can say that the placenta allows the connection and participates in the structural unit of the pregnant body, preventing collapse of identity or corporeal confusion.

However, it is not simply the woman's body that is pregnant. The whole woman is pregnant. She is pregnant. Moreover, at this point, it would be more correct to introduce the notion of "flesh" or "carnal being" to say that she is pregnant flesh bearing flesh. The word flesh has a relatively recent history. It starts from the philosophical remarks of Maine de Biran on one's own body and especially from Husserl's distinction between Körper and Leib that is between body and "living" body. Moreover, it is tied in Marcel's, Merleau-Ponty's, and Henry's philosophies to signify the particular kind of being that is the human being. Indeed, flesh does not indicate the Cartesian union of mind and body, neither "animated body" nor "embodied mind," neither spirit nor soul. It rather denotes the "subjectivity" of our experience as living beings that excess the mere materiality. Hence, the human body is both sensible and sentient; it is active in its own definition, as well as in the material changes.

In this view, the pregnant body is a pregnant, embodied subjectivity, or a flesh who is a subject. As Kristeva points out, the gestation is concerned with the maternal subjectivity considered as the site of her proceedings. Hence, at this level, "I," "experience," "feel" become the key words of a speech that can be pronounced only in the first person, leaving talk, to the extent that is possible, the "uniqueness" of that flesh. The pregnant woman is pregnant by virtue of inhabitation of her flesh by a body already made flesh. Her living experience is already deeply marked by the presence of the other, another subject who inhabits her body, who is at once a "separate" subject and a product "created" by her bodily environment; it is not utterly separable from her. For this reason, the experience of the pregnant woman is hard to tell. It is something to live, not to tell. And maybe just singing or poetic language, as Kristeva says, can express this corporeal abyss where the play between "You" and "l" become mutual dance. "This begins by the passion of the pregnant woman for herself: her destabilized "self," a loss of identity, because divided by the intervention of the lover-father, and, through this intervention of the other, inhabited by an unknown third party - an embryo, a fetus, then a baby, a child, though for the moment an indiscernible double, an a priori object, if you will, but in fact a formless pre-object, the empty content of a self-stimulated container in and against the link to the father-genitor and the environment. Although dominated by narcissism, this initial maternal passion is no less triangulated: the absent or inward-looking face of the one who is pregnant "looks" without "seeing" the father and the external world or the feelings of motion and emotion taking place in her body"11. For this reason, pregnant flesh seems to escape the analytical logic of thought with its categories of subject and object, self, and other. It contradicts any predicate and there is no model available to define its embodiment suspended between the one and the other, because it "is" at the same time both one and the other.

A pregnant subject experiences herself as split; her singularity seems to be apparently suspended, to be reaffirmed as different, but simultaneously as the same. Although the movements of the fetus are completely hers; nevertheless, they belong to another. They came from far away, and yet are so close as to be intimate, within her. The tremors in her belly are caused by the fetus and are at the same time her sensations. According to Young, in pregnancy the boundaries between within-myself and outside-separate become fluid. Indeed, the fetus is "inside," a part of herself, but it 
is another, separate. This feeling is confirmed by the experience of childbirth, where a part of my inside strains, presses and detaches from me: it is completely different from me, but it was inside of me as the innermost part of me. The belly hides and embodies the dichotomy between another and myself. It sticks out in front of me and blocks my passage, because the pre-pregnant body image does not leave my movement, but it does not break the integrity of the body.

Hence, the pregnant flesh seems to be animated by a double intentionality: that of her projects and purposes and that of her body that is still hers. And what is surprising is that the woman does not live this splitting and de-centralization as a situation of disease, often experiencing, as Young writes, a sense of power, solidity and validity.

Furthermore, the pregnant flesh has its own temporality of movement, in which the pregnant subject changes and grows with the growth of the other within herself. Both mother and fetus are in a process of becoming. Her "corporeal identity" is reformulated in an on-going and undirected process. Her singularity is transformed in participating in a creative process that will lead to the birth of herself as a mother and the child as her son. Although she does not direct it, she is the process, experiencing this change in depth in herself. Hence, each day, week, and month, the woman looks at her body and at herself for signs of transformation. Pregnancy time is different from clock time.

Thus, we could define pregnancy as an "actualizing of being," a unique situation in which the intimate presence of another who is just like herself becomes a deep and dialectic interplay between relationship and identification. And this is also the particular paradox of pregnancy: flesh within flesh, a relation in which two distinct individualities have at the same time radical otherness and radical oneness. This is a process that will transform all the actors involved: they will never be the same again. Indeed, the bodily change is visible for a few months and then disappears, leaving a figure sometimes identical. Instead, the woman's flesh becoming a mother has undergone a lasting and irreversible change, though almost invisible. For this reason, pregnant embodiment enables a unique relationship to past and future where the apparent "loss" of identity is actually the surprising "transition" to a "new" maturation of the self. Thus, in this reading, the identity of the pregnant subject, is not threatened or suspended through the multiplication implicit in pregnancy, but is rather expanded and altered by the shifting corporeal terrain.

\section{The ethics of pregnancy: taking care of oneself "as" and "because" another}

From what I have described, it has turned out that adopting a phenomenological approach is quite useful and interesting in describing pregnancy. It has allowed to characterize human gestation as an eminently relational situation in which selfhood refers to the otherness caught in a physical and psychic proximity ${ }^{6}$.

Traditional speculation has always maintained that the peculiar meaning of otherness would be extraneousness, which could only be accessed through the modes of conflict or, in any case, of distance. On the contrary, gestation presents itself as a particular situation in which the relationship to the other is consummated at the very heart of intimacy ${ }^{12}$. In this sense, it offers a different, 
"specifically feminine," declination of the relationship between you and I, in which between subject and object there would be no contradiction, nor even opposition, but rather a relationship of understanding, agreement and harmony lived intensely.

Precisely for this reason, as also recognizes Irigaray, a reflection on pregnancy is an extremely difficult task. It forces to think about a subjectivity that is not in princeps and well defined position, that is, that it fully possesses itself and the action it accomplishes, but which, being in a certain sense dynamic, is regained only at the end of the process. Neither the mother nor the fetus control its development, yet there are its main characters.

Therefore, being a double process of formation and change of the self, human gestation seems to require also a new characterization of the notion of the identity, caught in its temporally and relationally dynamic essence. The relationship with otherness becomes an integral part of the self to be constitutive of it. Thus, oneself results "as" and "because" another and this at a double level.

In the case of the embryo, day by day its identity goes forging in the continuous emotional exchanges that take place with the mother and, through her, with the outside world. In this regard, recent and important studies are showing that the fetus inside the uterus has most of the features, we associate with the newborn baby ${ }^{13-15}$. Furthermore, the innate sociality of the newborn child is a clear sign that the unconscious I begins in the trans-sensible pre-subjects trans connectivity to the pregnant woman as a subjectivizing agency ${ }^{16}$. According to Kristeva, the mother would have an indispensable regulative function, already educational, since the vocalic, gestural, and bodily relationship she establishes with the fetus would already be a process of signification and would constitute the basis or condition on which the symbolic order will be insert, allowing the child to become speaking and to enter the social sphere ${ }^{17}$.

Regarding the identity of the woman, her subjectivity in pregnancy is not only divided, but she experiences herself dialectically as the source and protagonist of a generative process that also concerns herself. Even if she does not direct it; nevertheless, it comes down on her as indifferent. Rather, she is the process and the change ${ }^{9}$. Precisely for this reason, the delivery and the birth of the child represent a beginning, but they are also the conclusion of a maturative process of the self that takes place during the 9 months and that the woman desires and fears ambivalently. In this sense, the pregnant woman carries the other inside herself, but she is also carried by the fetus.

Thus, as Kristeva recognizes, the pregnant body would appear as a place of deep contact between the semiotic and the symbolic, the threshold of adherence between nature, the biological sphere, moved by its own and other causality with respect to the symbolic, and culture.

Furthermore, the phenomenological approach has shown that pregnancy has a relational meaning, carnally lived, which deeply affects the identity of the subjects involved in its dialectic becoming. Precisely as an experience of the flesh, it is indelibly inscribed in its original memory, furrowing it in the depths. If the delivery seems to break the organic bond, it cannot tear the carnal mark of the other in oneself. It is so-internal and external and, as such, indelible $e^{18-21}$. 
Thus, the most proper essence of pregnancy can be grasped only by placing in its specific relationality that distinguishes it in its intimate dialecticity and apparent contradiction. Relationality that declines the ethical implementation proper to pregnancy as responsibility and taking care of another that is responsibility for oneself.

From this point of view, in human gestation the other would not be what limits my autonomy, but what with its presence awakens my freedom to its exercise. The freedom would be activated as free will, but urged by the experience of the good of the relationship to look for one's own good and one's self-realization. Indeed, in the case of a pregnancy, we are in the presence of particular "relational goods"22-24 that can only be achieved by placing in its "in-between," rather than taking a certain point of view simplistically, subordinating, or, worse still, renouncing that of others.

The presence of a common and shared "in-between," with its specific modalities of explication for each side of the relationship, would prevent the a-priori and abstract assumption of a particular "interest." The danger is the loss of the whole relationship and its ethical actualization as violence against the other, but above all against oneself.

Human gestation is the first structure of "living together," only apparently asymmetric. It is characterized by a specific mutuality and by a distinct dialectical movement implying a reciprocal "dwelling;" it attests to the typical ontological deficiency of the human being originating the dialectical openness to the other, which is called to provide what an individual is not capable to achieve by itself.

Here, the problem is evidently the difficulty of categorizing and framing of an eminently relational situation, in which oneself means at the same time otherness.

Precisely for this reason a systematic reflection on pregnancy from the perspective of the articulation of the uterine bond between mother and fetus seems to be a particularly urgent speculative task. Especially since this relationship appears to be "original," both from a chronological and, anthropologically speaking, an ontological point of view. As the beginning, it characterizes the history of every human being, drawing the traits of its identity. The stakes are very high, because they concern the humanity, we are "generating" and delivering to the future. And the danger could be very big, if, as Kristeva claims, "it follows that any loss entails the loss of my being-and of being itself" 25 .

\section{Funding}

This research has not received any specific grants from public, commercial, or non-profit agencies.

\section{Conflicts of interest}

The author declares that she have no conflicts of interest. 


\section{Ethical disclosures}

Protection of human and animal subjects. The author declares that no experiments were performed on humans or animals for this study.

Confidentiality of data. The author declares that no patient data appear in this article.

Right to privacy and informed consent. The author declares that no patient data appear in this article.

\section{References}

1. Ranjbar F, Akhondi M, Borimnejad L, Ghaffari S, Moghadam Z. Paradox of modern pregnancy: a phenomenological study of women's lived experiences from assisted pregnancy. J Pregnancy. 2015;1-8.

2. Tyler I. Skin-Tight: celebrity, pregnancy and subjectivity. In: Ahmed S, Stacey J., editors. Thinking through the Skin. London, New York: Routledge; 2001. p. 69-83.

3. Oliver K. Knock me Up, Knock me Down: images of Pregnancy in Hollywood Films. New York: Columbia University Press; 2012.

4. O'Brien M. The Politics of Reproduction. London: Routledge; 1983.

5. Adams SL, Lundquist C. Coming to life. In: Philosophies of Pregnancy, Childbirth and Mothering. New York: Fordham University Press Publication; 2012.

6. Irigaray L. Speculum of the other Woman. Ithaca, New York: Cornel University Press; 1985.

7. Kristeva, J. Motherhood according to Giovanni Bellini. In Roudiez, LS. Desire in Language: A Semiotic Approach to Literature and Art. New York: Columbia University Press; 1980. P. 237-270.

8. Irigaray L. This Sex which is not One. Ithaca: Cornell University Press; 1985.

9. Young I. Pregnant embodiment: subjectivity and alienation. J Med Philos. 1984;9:45-62.

10. Maher J. Visibly pregnant: toward a placental body. Fem Rev. 2002;72:95-107.

11. Kristeva J. Hatred and Forgiveness. New York: Columbia University Press; 2010

12. Mottini-Coulon E. Essai D'ontologie Spécifiquement Feminine. Paris: Librairie Philosophique J. Vrin; 1978.

13. Piontelli A. From Fetus to Child: an Observational and Psychoanalytical Study. London: Routledge; 1992.

14. Paul AM. Origins: how the Nine Months Before Birth Shape the Rest of Our Lives. New York: Free Press; 2010.

15. Gluckman P, Hanson M. The Fetal Matrix: evolution, Development and Disease. New York: Cambridge University Press; 2004.

16. Trevarthen C, Aitken K. Infant intersubjectivity: research, theory and clinical applications. J Child Psychol Psychiatry. 2001;42:3-48.

17. Kristeva J. Revolution in Poetic Language. New York: Columbia University Press; 1984.

18. Lavin CG, García RZ. Categorización diagnóstica del síndrome post aborto. Actas Españolas Psiquiatría. 2005;33:267-72.

19. Fergusson DM, Horwood LJ, Boden JM. Abortion and mental health. Br J Psychiatry. 2009;194:377-8.

20. Templeton A, Grimes DA. A request for abortion. N Engl J Med 2011;365:2198-204.

21. Verny T, Kelly J. The Secret Life of the Unborn Child. New York: Dell Publishing; 1981.

22. Nussbaum MC. The Fragility of Goodness: luck and Ethics in Greek Tragedy and Philosophy. New York: Cambridge University Press; 1986.

23. Donati P. Teoria Relazionale Della Società. Milano: FrancoAngeli; 1991

24. Donati P, Solci R, Relazionali IB. Che Cosa Sono e Quali Effetti Producono. Torino: Bollati Boringhieri; 2011.

25. Kristeva J. Black Sun: depression and Melancholia. New York: Columbia University Press; 1989. 